\title{
THE KIRPAN: JUSTIFIED DOCTRINE OR JUST A DAGGER? -
}

WHEN RELIGIOUS SYMBOLS CLASH WITH PUBLIC SAFETY

SUKHRAAJ SHERGILL

\section{LS 102 - INTRODUCTION TO CRIMINAL LAW}

Freedom and security are often seen as opposites in modern society. One must be relinquished in part to further a sense of the other. Religious rights under section $2 \mathrm{a}$ of the Canadian Charter of Rights and Freedoms (1982) are often contrasted with the legal right to life, liberty and security under section 7 and the concept of public safety as was the case with Multani v. Commission scolaire Marguerite-Bourgeoys (Multani v. Commission scolaire MargueriteBourgeoys, 2006 SCC 6, [2006] 1 SCR 256). The Multani v. Commission scolaire MargueriteBourgeoys case centered around the sheathed Kirpan Mr. Multani, a twelve year-old baptized Sikh, carried; which fell from its strap, still sheathed on a playground. The case reached the Supreme Court of Canada as it concerned the religious article: the Kirpan. If the Supreme Court of Canada had ruled in favour of removing the Kirpan from Gurbaj Singh Multani, the Court would be impeding his beliefs and be damaging to his sense of identity, as it would also encroach on religious rights. Section 2a of the Canadian Charter of Rights and Freedoms states, "[e]veryone has the following fundamental freedoms: (a) freedom of conscience and religion" (The Constitution Act, 1982). This paper will synthesize the Multani argument under section 2a of the Canadian Charter of Rights and Freedoms (1982) and explain the significance of the Kirpan before progressing to synthesize the Commission scolaire Marguerite-Bourgeoys' argument under section 7 of the Canadian Charter of Rights and Freedoms (1982). The paper will also lay out a preliminary 
understanding of section 88(1) of the Criminal Code of Canada as it explains the definition of a weapon in relation to section 267 of the Criminal Code of Canada, the crime of assault as related to the Commission scolaire Marguerite-Bourgeoys' argument. The paper will then close by summarizing the Supreme Court of Canada's judgement on the matter.

Firstly, in support of the Multani argument utilizing section 2a of the Canadian Charter of Rights and Freedoms (1982), the Kirpan is a religious requirement for all baptized Sikhs, formally known as Amritdhari Khalsa Sikhs (Jhutti-Johal, 2011, p. 96-97). It is essentially a dagger or ceremonial sword worn by baptized Sikhs that is a defensive article in the direst of circumstances. However, the Commission scolaire Marguerite-Bourgeoys argued that the Kirpan is indeed a weapon that can be used to injure people. Therefore, the Commission asserted that the Kirpanis a dangerous article that has implications when regarding sections 7 and 1 of the Canadian Charter of Rights and Freedoms (1982) in conjunction with interpretations of sections 88(1) and 267 of the Criminal Code of Canada (1985). Finally, resolving these two standpoints, restrictions can be enforced to protect public safety in conjunction with accommodating the Kirpan and maintaining rights guaranteed by the Canadian Charter of Rights and Freedoms (1982), as well as the Universal Declaration of Human Rights (1948), and the International Covenant on Civil and Political Rights (1966).

Primarily, the Kirpan is an integral part of the Sikh religion, belief, and identity. It is one of the five articles that are compulsory for baptized Sikhs. These five articles are considered the uniform of a Sikh,

...each beginning with the Gurmukhi letter $k$. These are kes (uncut hair), a kangha (comb), a kirpan (dagger or short sword), a kara (wrist-ring of either iron or steel) and kachh (shorts that must not reach below the knee). [Baptized] Sikhs...promise to wear the Five K's. (McLeod, 2008, p.326-327). 
These Sikhs swear to have the Five K's with them at all times. The value of the Kirpan stretches beyond the guarantees of religious freedom in the Canadian Charter of Rights and Freedoms (1982) and has historical significance to Sikhs.

The Kirpan is entrenched in the history of the Sikhs. The Five K`s commemorate historical events for Sikhs such as when the ninth Guru, Guru Tegh Bahadur Sahib Ji, was executed for protecting the religious rights of the Hindus (Johar, 1975, p. 192-210). During this era, Sikhs were not distinguishable from the rest of the populace. The Five K`s gave a distinct appearance to Sikhs. The Kirpan furthered this distinct appearance as it aligned and solidified the intangible moral obligation of Sikhs with the tangible concept of the Kirpan, to become "an instrument of compassion to be used to protect and safe-guard [the] dignity or honour of others" (Bachu, 1996, p. 203). Sikhs view the Kirpan as a defensive tool that is used strictly to help others and not to be used in an offensive manner.

Furthermore, the meaning and reasoning behind the Kirpan itself is "...derived from the Sanskrit words Kirpa and Aan meaning mercy or compassion and honour or dignity" (Singh, 2005, p. 287). It is perceived as a symbol that represents a "...duty to fight for good over evil, and to always support freedom above oppression" (Bagga, 2006, p. 7). The Kirpan has an inherently noble meaning rooted in the Sikh belief itself and is meant to be a positive symbol as the Multani argument represented it. The ties of the Kirpan to the Sikh religion connect the article of faith to the religion and subsequently, section 2a of the Canadian Charter of Rights and Freedoms (1982). The Kirpan is not to be utilized in a violent manner; which stands in stark contrast to its attempted characterization by the Commission scolaire Marguerite-Bourgeoys as an offensive weapon.

Conversely, the Commission scolaire Marguerite-Bourgeoys brought forth the point that the Kirpan, while being an article of faith with defensive and benevolent connotations, still carries the potential to be a fatal weapon and thus could have detrimental effects on public safety. In 
essence, the Commission asserted that the Kirpan is a ceremonial dagger and that a dagger is, by definition a "...weapon designed to kill, intimidate or threaten others" (Schutter, 2010, p. 354). Religious affiliations aside, the Kirpan, without restrictions, does indeed carry with it the capacity to severely wound a person if used. Before the decision of the Supreme Court of Canada in the Multani v. Commission scolaire Marguerite-Bourgeoys case, the Kirpan was allowed in schools subject to the condition that it be "...strapped...[and] riveted to [its sheath] or the blade was blunt with a rounded tip" (Hamilton, 2005, p. 115-116). This meant that prior to the Supreme Court decision; schools were required to restrict the Kirpan to only a cloth strap - both of which could be undone relatively easily - and a dull blade. These restrictions could, at the discretion of the individual school district be augmented by the option of riveting the blade to its sheath. However, leaving this choice to individual school boards and avoiding a standard leaves the option that the Kirpan could still be utilized if the school board did not employ the option of riveting. If the Kirpan were to ever be utilized, even a dull blade could pierce flesh in a fatal manner. As this is a recognized threat, the school district's decision to make a safety measure such as riveting optional and not required, still provides the chance of use. It is clear that the Kirpan, with religious status removed, becomes a fatal weapon with unreasonable restrictions that has the potential to violate section 7 of the Canadian Charter of Rights and Freedoms (1982).

Section 7 of the Canadian Charter of Rights and Freedoms (1982) states that "[e]veryone has the right to life, liberty and security of the person and the right not to be deprived thereof except in accordance with the principles of fundamental justice" (The Constitution Act, 1982). The Kirpan essentially becomes a weapon that has the capacity to deprive someone of their right to life and security of the person as it can be used in an offensive manner. It has the capability to be used to injure another person and at this point becomes strictly a dagger with no religious significance; as 
well as an entirely real threat to the security of the person while restrictions on length serve to further counteract the effectiveness of the Kirpan as a weapon (Fox, 1985, p. 114-115).

Furthermore, section 88(1) of the Criminal Code of Canada (1985) states that "[e]very person commits an offence who carries or possesses a weapon, an imitation of a weapon, a prohibited device or any ammunition or prohibited ammunition for a purpose dangerous to the public peace or for the purpose of committing an offence". This section of the Criminal Code of Canada (1985) specifically states that anyone who “...carries or possesses a weapon...for a purpose dangerous to the public peace..." (Criminal Code, section $88(1)$ ), is guilty of a criminal offence. However, one must be careful in interpreting section $88(1)$ or any law, down to the letter. As the option to interpret the law in question via a lens that focuses on the intention of the law in contrast to its literal meaning exists, the Kirpan is reasonable to possess and carry. The intention of the law is not to supress religious freedoms. However, applying a literal understanding of section 88(1) creates a scenario where, a Kirpan, with its religious significance removed, essentially becomes just a dagger that has the sole purpose of being a danger to the public peace. This is not to mention that the mere act of being in possession and carrying the Kirpan would constitute an offence (Nkomo, 2011).

The Commission scolaire Marguerite-Bourgeoys, applying a literal analysis of section 88(1) of the Criminal Code of Canada (1985), raised the legal principle of inchoate offences and the concept of preventing a crime prior to its occurrence. Inchoate offences are "...a unique class of criminal offences in the sense that they criminalize acts that precede harmful conduct but do not necessarily inflict harmful consequences in and of themselves" (Chapman, 2014, p. 245). The crime of assault under section 267 of the Criminal Code of Canada (1985) is defined as

[e]very one who, in committing an assault, $(a)$ carries, uses or threatens to use a weapon or an imitation thereof, or $(b)$ causes bodily harm to the complainant, is 
guilty of an indictable offence and liable to imprisonment for a term not exceeding ten years or an offence punishable on summary conviction and liable to imprisonment for a term not exceeding eighteen months. (Criminal Code, section 267).

When the principle of inchoate offences is applied to the Criminal Code of Canada's (1985) definition of committing an assault and further applied to the Kirpan, an assault with the Kirpan is a preventable offence. This is applicable by removing the religious significance of the Kirpan, in which case it becomes strictly a dagger with the purpose and ability of causing harm. The Multani v. Commission scolaire Marguerite-Bourgeoys case brought forth the intriguing broad notion of whether religious rights and security rights - specifically the Kirpan and public safety rights could coexist peacefully. Further, the Supreme Court of Canada upheld that the spirit of the law is greater than the letter of the law. The Court answered the notion by upholding restrictions on the length, casing and maintenance of the Kirpan while disregarding the literal application of section 267a of the Criminal Code of Canada (1985) as simply carrying the Kirpan would once again constitute an offence.

Ultimately, the responsibility to reconcile the "freedom of religion" (The Constitution Act, 1982) under section $2 \mathrm{a}$ and the right to "... life, liberty and security..." (The Constitution Act,1982) under section 7 of the Canadian Charter of Rights and Freedoms (1982) fell upon the Supreme Court of Canada. It had to decide if a total ban on the Kirpan was justified by applying the $R$. $v$. Oakes (R. v. Oakes, [1986] 1 S.C.R. 103) test in relation to section 1 of the Canadian Charter of Rights and Freedoms (1982). Section 1states that "[t]he Canadian Charter of Rights and Freedoms guarantees the rights and freedoms set out in it subject only to such reasonable limits prescribed by law as can be demonstrably justified in a free and democratic society" (The Constitution Act, 1982). 
The well-established $R$. v. Oakes test lays out the process that the Court must use to determine if a violation of a right or freedom guaranteed by the Canadian Charter of Rights and Freedoms has occurred. The test begins once a violation of a protected right or freedom has occurred. The Court must then determine if the law in question provides a reasonable restriction that follows section 1 of the Canadian Charter of Rights and Freedoms (1982). Finally, should the law fail to be a reasonable restriction; the Court can strike it down (Oakes, 2013). The Supreme Court of Canada in the Multani v. Commission scolaire Marguerite-Bourgeoys case was convinced that the not allowing Gurbaj Singh Multani to attend the school with his Kirpan was a violation of his section 2a right under the Canadian Charter of Rights and Freedoms (1982). This violation invoked the procedure of the R. v. Oakes test and the Court decided that upholding the conditions placed upon the Kirpan by the Superior Court of Quebec constituted a reasonable step that protected both rights under the Canadian Charter of Rights and Freedoms. These conditions were that,

the Kirpan was to be worn under the student's clothes; the Kirpan was to be placed in a wooden sheath and wrapped and sewn securely in a sturdy cloth envelope, which was to be sewn to a shoulder strap (guthra); the student was required to keep the Kirpan in his possession at all times, and its disappearance was to be reported to school authorities immediately; school personnel were authorized to verify, in a reasonable fashion, that the conditions for wearing the Kirpan were being complied with; and if these conditions were not complied with, the student would definitively lose the right to wear a Kirpan. (Multani v. Commission scolaire MargueriteBourgeoys, 2006 SCC 6, [2006] 1 SCR 256, para. 88).

These conditions made the Kirpan become almost impossible to use as an offensive or defensive weapon by being wrapped in repetitive sheets of cloth, further encased in a wooden sheath and, finally, being sewn into a shoulder strap. In this way, the restrictions satisfied the requirement of section 7 of the Canadian Charter of Rights and Freedoms (1982) by removing almost any chance 
of using the Kirpan to harm the life, liberty or security of a person as the Kirpan could not be efficiently removed from its security measures to assault someone with.

The decision of the Supreme Court of Canada nullified any likelihood of the Kirpan being utilized as a weapon via the imposition of a set of security measures and conditions which served essentially as an ultimatum: either the conditions would be met or the Kirpan would be removed. This decision followed a similar vein as that of the Grant v. Canada case, which also centered on section 2a (Grant v. Canada (Attorney General), 1994 CanLII 3507 (FC), [1995] 1 CF 158) and the R. v. Badesha case, which centered on sections $2 \mathrm{a}$ and 7 of the Canadian Charter of Rights and Freedoms (1982), (R. v. Badesha, 2010 ONCJ 10 (CanLII)). In both cases the section 2a rights of Sikhs in Canada were upheld. At issue in those cases were whether the Turban was against the uniform regulations of the Royal Canadian Mounted Police (Grant v. Canada (Attorney General), 1994 CanLII 3507 (FC), [1995] 1 CF 158) and whether the Turban was against motorcycle regulations, (R. v. Badesha, 2010 ONCJ 10 (CanLII)) respectively.

The restrictions imposed by the Supreme Court of Canada allowed the Kirpan to remain in the possession of the Sikh who was to be carrying it without changing the Kirpan itself. In this way, the restrictions were a reasonable violation of section $2 \mathrm{a}$ of the Canadian Charter of Rights and Freedoms (1982). The religious article was retained as the religion dictated while its actual use was limited in an effort to balance the rights of the public under section 7 of the Canadian Charter of Rights and Freedoms (1982).

Furthermore, the Supreme Court of Canada's decision to uphold the Superior Court of Quebec's conditions solidified the integral value of Canadian society that is multiculturalism (Multani v. Commission scolaire Marguerite-Bourgeoys, 2006 SCC 6, [2006] 1 SCR 256, para. 71). The decision however, did not give an unlimited right to Sikhs in that the Kirpan was heavily 
shielded and rendered useless in a confrontation. The Supreme Court of Canada concluded that the Kirpan was not a weapon and was tied to a sincerely held religious belief, such that its restriction would violate section 2a of the Canadian Charter of Rights and Freedoms (1982). However, the Supreme Court of Canada also recognized, under section 1 of the Canadian Charter of Rights and Freedoms (1982), that the restrictions on the religious freedom to bear the Kirpan; imposed by the Superior Court of Quebec, were reasonable and justified limits. Limits that were employed to minimally impair the right to religious freedom and also to ensure public safety as the Kirpan had the potential to pose a risk to public safety. The restrictions virtually removed that threat while preserving the religious right to bear the symbol (Multani v. Commission scolaire MargueriteBourgeoys, 2006 SCC 6, [2006] 1 SCR 256).

This decision by the Supreme Court of Canada has spread farther than the Kirpan in the school environment and beyond the borders of Canada itself. The decision is not only accommodating of sections 2a and 7 of the Canadian Charter of Rights and Freedoms (1982), but also Article 18 of two separate United Nations documents: the Universal Declaration of Human Rights (1948), and the International Covenant on Civil and Political Rights (1966), both of which Canada has signed and ratified (Barnett, 2.1). These two United Nations documents parallel sections 2a and 7 of the Canadian Charter of Rights and Freedoms (1982) (refer to Appendix A for the respective texts of the United Nations documents). As such, the decision of the Supreme Court of Canada regarding the Multani v. Commission scolaire Marguerite-Bourgeoys case can be seen as informative in the interpretation of both the Canadian Charter of Rights and Freedoms (1982) context and in the context of these international rights documents.

The Multani v. Commission scolaire Marguerite-Bourgeoys case pitted against each other sections 2a and 7 of the Canadian Charter of Rights and Freedoms (1982) with regards to the 
Kirpan and public safety. The Kirpan is a religious necessity for baptized Sikhs, but with the religious affiliation removed it becomes a simple weapon that is dangerous to public safety. Stipulations can be placed on the Kirpan, which entertain the concerns raised by section 7, and uphold the rights under section 2a of the Canadian Charter of Rights and Freedoms (1982) as well as Article 18 of the Universal Declaration of Human Rights (1948) and International Convent on Civil and Political Rights (1966). To Sikhs, it is a sacred duty not to use the Kirpan in aggression and only to defend another person in a life or death situation (Singh et al., 2016, p. 29). However, relying on simple reasonable faith to prevent the misuse of such articles of faith cannot be allowed, as the actions of an individual are unpredictable and may cause severe harm to another as well as to the notion of safety in society. In addition to the conditions placed on the Kirpan by the Supreme Court of Canada, a restriction should be added that the Kirpan be welded shut or riveted to its original sheath and that sheathed Kirpan be placed within the manifold security measures upheld by the Supreme Court of Canada to render the Kirpan completely useless in a confrontation. It is the duty of a Sikh to fight against aggression, oppression and to protect the weak. As the tenth Sikh Guru, Guru Gobind Singh Ji stated, "[i]f all other peaceful means failed to uproot tyranny then it was right to take up the sword" (Bedi, 1968, verse 22). 


\section{Appendix A}

\section{$\underline{\text { Universal Declaration of Human Rights: Article } 18}$}

[e]veryone has the right to freedom of thought, conscience and religion; this right includes freedom to change his religion or belief, and freedom, either alone or in community with others and in public or private, to manifest his religion or belief in teaching, practice, worship and observance (Universal Declaration of Human Rights: Article 18).

\section{International Covenant on Civil and Political Rights: Article 18}

Article 18 - Sections 1 and 2

1. Everyone shall have the right to freedom of thought, conscience and religion. This right shall include freedom to have or to adopt a religion or belief of his choice, and freedom, either individually or in community with others and in public or private, to manifest his religion or belief in worship, observance, practice and teaching.

2. No one shall be subject to coercion, which would impair his freedom to have or to adopt a religion or belief of his choice (International Covenant on Civil and Political Rights: Article 18). 


\section{References}

Bachu, A. S. (1996). A Shield for Swords. American Criminal Law Review, Vol. 34(No. 1), 197224.

Bagga, R. S. (2006). Living by the Sword: The Free Exercise of Religions and the Sikh Struggle for the Right to Carry a Kirpan. Modern American, Vol. 2(No. 3), 32.

Barnett, L. (2011, July 25). Current Publications: Law, justice and rights: Freedom of Religion and Religious Symbols in the Public Sphere Freedom of Religion and Religious Symbols in the Public Sphere (2011-60-E). Parliament of Canada Web Site - Site Web du Parlement du Canada. Retrieved February 18, 2013, from http://www.parl.gc.ca/Content/LOP/ResearchPublications/2011-60-e.htm\#a7

Bedi, G. S. (1968). The Epistle of Victory: an English translation of Guru Gobind Singh's Zafarnama in verse (3rd ed.). Amritsar: Satvic Media Pvt. Ltd.

Chapman, F. E. (2014). Introduction to Legal Studies. Toronto: Nelson Education.

Criminal Code, R.S.C. 1985, c. C-46, s. 17; R.S.C. 1985, c. 27 (1st Supp.)

Fox, R. G. (1985). Lions of the Punjab: the Sikhs and British India's culture in the making. Berkeley: University of California Press. 114

Grant v. Canada (Attorney General), 1994 CanLII 3507 (FC), [1995] 1 CF 158, http://canlii.ca/t/4gk9 retrieved on 2013-02-18.

Hamilton, M. (2005). God vs. the Gavel: Religion and the rule of law. Cambridge: Cambridge University Press. 115

H., Singh, S., Singh, \& J., Singh. (2016). Sikh Code of Conduct: A guide to the Sikh way of life and ceremonies (5th ed.). Anandpur, Punjab: Akaal. International Covenant on Civil and Political Rights. (n.d.). OHCHR Homepage. Retrieved February 18, 2013, from http://www2.ohchr.org/english/law/ccpr.htm 
Johar, S. S. (1975). Guru Tegh Bahadur - A Biography. Madison: University of WisconsinMadison Center for South Asian Studies Press.

Jhutti-Johal, J. (2011). Sikhism Today. London: Continuum.

McLeod, H. (2008). The Five K's of the Khalsa Sikhs. Journal of the American Oriental Society, Vol. 128(No. 2), 326-327.

Multani v. Commission scolaire Marguerite-Bourgeoys, 2006 SCC 6, [2006] 1 SCR 256

Nkomo, S. (2011). Moving from the Letter of the Law to the Spirit of the Law: The challenges of realizing the intent of employment equity and affirmative action.

Transformation: Critical Perspectives on Southern Africa Transformation, 77(1), 122135.

Oakes Test. (2013). Retrieved April 25, 2016, from http://ualawccsprod.srv.ualberta.ca/ccs/index.php/i-o/774-oakes-test

R. v. Badesha, 2010 ONCJ 10 (CanLII), <http://canlii.ca/t/27qkz> retrieved on 2013-02-20

Schutter, O. d. (2010). International Human Rights Law Cases, Materials, Commentary. Cambridge: Cambridge University Press. 354

Singh, K. (2005). History and Philosophy of the Sikh Religion Part II. Amritsar: Satvic Media Pvt. Ltd.. (Original work published 1914), 287

The Constitution Act, 1982, being Schedule B to the Canada Act 1982 (U.K.), 1982, c. 11. Universal Declaration of Human Rights: Article 18. (n.d.). Universal Declaration of Human Rights 50th Anniversary - UDHR50 - Main Menu Frames Version. Retrieved February 10, 2013, from http://www.udhr.org/UDHR/ART18.HTM 